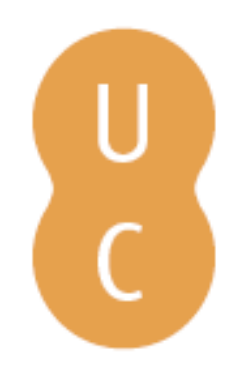

\title{
nombalina
}

\section{"Dar de comer a quem tem fome": a dieta alimentar dos pobres e doentes de Coimbra na Idade Média}

\author{
Autor(es): $\quad$ Rocha, Ana Rita \\ Publicado por: Imprensa da Universidade de Coimbra \\ URL \\ persistente: URI:http://hdl.handle.net/10316.2/45230 \\ DOI: $\quad$ DOI:https://doi.org/10.14195/978-989-26-1721-3_3 \\ Accessed : $\quad$ 26-Apr-2023 00:38:12
}

A navegação consulta e descarregamento dos títulos inseridos nas Bibliotecas Digitais UC Digitalis, UC Pombalina e UC Impactum, pressupõem a aceitação plena e sem reservas dos Termos e Condições de Uso destas Bibliotecas Digitais, disponíveis em https://digitalis.uc.pt/pt-pt/termos.

Conforme exposto nos referidos Termos e Condições de Uso, o descarregamento de títulos de acesso restrito requer uma licença válida de autorização devendo o utilizador aceder ao(s) documento(s) a partir de um endereço de IP da instituição detentora da supramencionada licença.

Ao utilizador é apenas permitido o descarregamento para uso pessoal, pelo que o emprego do(s) título(s) descarregado(s) para outro fim, designadamente comercial, carece de autorização do respetivo autor ou editor da obra.

Na medida em que todas as obras da UC Digitalis se encontram protegidas pelo Código do Direito de Autor e Direitos Conexos e demais legislação aplicável, toda a cópia, parcial ou total, deste documento, nos casos em que é legalmente admitida, deverá conter ou fazer-se acompanhar por este aviso.

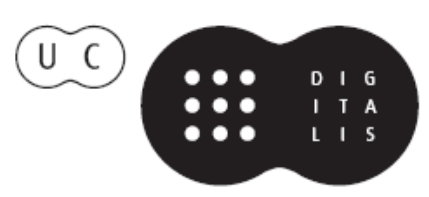


Carmen Soares

Gilene da Silva Gomes Ribeiro

(coords.)

\section{Mesas \\ LUSO-BRASILEIRAS}

\section{ALIMENTAÇÃO, SAÚdE \& GULTURA}

\section{VOLUME I}

IMPRENSA DA UNIVERSIDADE DE COIMBRA COIMBRA UNIVERSITY PRESS

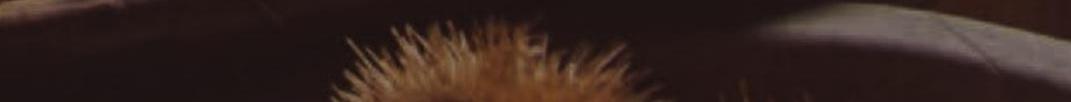




\title{
"DAR de COMER A QUEM TEM FOME": A DiETA Alimentar dos pobres e doentes de Coimbra na Idade Média
}

\author{
(“To feed the hungry": The diet of poor and sick in medieval Coimbra)
}

\author{
Ana Rita Rocha \\ Universidade de Coimbra, Faculdade de Letras \\ CHSC/Projeto DIAITA \\ (anarita.srocha@gmail.com)
}

RESUMO: Este artigo tem por objetivo demonstrar de que modo a sociedade conimbricense praticou a primeira das obras de misericórdia corporais: "Dar de comer a quem tem fome". Pretendemos apresentar como se proveu o sustento alimentar dos pobres e doentes, na cidade de Coimbra, ao longo da Idade Média, e como, dessa forma, se cuidou de corpos fragilizados tanto pela miséria, como pela doença. Primeiro, no contexto de desenvolvimento da designada "economia da salvação", analisaremos os legados testamentários compostos por géneros alimentares ou quantias em dinheiro destinadas a comprar estes produtos para os pobres. Neste sentido, é nosso objetivo verificar que alimentos compunham esses legados, para perceber quais os mais frequentemente repartidos pelos indigentes e enfermos da cidade, e analisar como se distribuíam ao longo do calendário. Num segundo momento, centraremos a nossa atenção no provimento alimentar oferecido pelas confrarias e hospitais de Coimbra, responsáveis por acolher pobres e doentes, que aqui encontravam condições básicas de sobrevivência. Destacaremos o Hospital de Santa Isabel e o Hospital de S. Lázaro, para os quais se conhecem as rações individuais distribuídas a partir de 1328 e 1329 , respetivamente.

PALAVRAS-CHAVE: dieta alimentar, legados pios, pobres, doentes, leprosos, hospitais, confrarias, Coimbra, séculos XII-XIV.

ABSTRACT: This paper aims to analyse how the first corporal work of mercy, "To feed the hungry", was practiced by the Coimbra's society. We intend to present the way the poor and the sick were fed in the medieval city of Coimbra, and also how their bodies weakened by poverty and disease were care. First, in the context of the development of the "economy of salvation", we'll analyse the testamentary donations to the poor of food or the money to buy it. Thus, it's our purpose to confirm how these legacies were comprised, to understand which food was most often given to the city's poor and sick and the alms distribution framework along the calendar. Secondly, we'll focus in the food offered by Coimbra confraternities and hospitals, which provided basic survival conditions to the poor and sick. We'll emphasize the 
examples of Saint Elisabeth and Saint Lazarus hospitals, for which we know the individual provisions distributed since 1328 and 1329, respectively.

KEYWORDS: diet, pious wills, poor, sick, lepers, hospitals, confraternities, Coimbra, XII ${ }^{\text {th }}-X I V^{\text {th }}$ centuries.

"Dar de comer a quem tem fome". Assim encorajava a Igreja medieval os seus crentes, através de uma das mais importantes obras de misericórdia corporais, a alimentar os famelici ou esfomeados, aqueles que pouco ou nada tinham para suprir as suas necessidades fisiológicas básicas, numa sociedade que Jacques Le Goff tão bem caracterizou como fortemente marcada pela fome ${ }^{1}$.

Os cristãos encontravam na prática da caridade, desenvolvida, sobretudo, a partir dos séculos XI e XII, um meio de materialização das obras de misericórdia. Doando parte dos seus bens terrenos aos mais necessitados, podiam não só prestar-lhes socorro, minimizando as suas carências, como obter benefícios para si próprios, a que teriam acesso após a morte. Por norma, os mais poderosos recorriam à sua última vontade, registada no testamento, para legar somas em dinheiro ou outros bens materiais aos pobres. Estes donativos podiam, pois, consistir em produtos alimentares ou em dinheiro destinado à sua compra, doados com o objetivo de alimentar aqueles que, fruto das suas privações, sofriam com o flagelo da fome ${ }^{2}$. Essa era, portanto, uma das vias para a prática da primeira das obras de misericórdia corporais ${ }^{3}$.

Os meios para alimentar os pobres e enfermos não se esgotavam nas esmolas, que podiam ser legadas em testamento ou distribuídas diretamente aos mendigos. Neste aspeto, as instituições caritativas, que se foram desenvolvendo, em particular, a partir dos séculos XII-XIII, assumiram, entre as suas funções, a de alimentar aqueles que nelas procuravam acolhimento. Assim, albergarias e hospitais, gafarias e, de uma forma um pouco diferente, como iremos ver, confrarias não deixaram de fornecer aos seus habitantes e assistidos alguns dos alimentos básicos da dieta medieval.

Deste modo, ao longo da Idade Média, a sociedade encontrou nas esmolas e nas instituições de assistência uma forma de alimentar os indigentes e enfermos, concedendo-lhes, pelo menos, parte do seu sustento e dos nutrientes necessários à sua sobrevivência e fortalecimento.

${ }^{1}$ Le Goff 2008: 205.

2 Cf. López Alonso 1986: 83-86.

${ }^{3}$ Sobre as relações estabelecidas entre ricos e pobres, veja-se, para uma breve contextualização, Geremek 1995: 27-48; Tavares 1989: 63-67. 


\section{Os legados aOS POBRES: A DISTRIbUiçÃo DE ALIMENTOS}

Como dito anteriormente, os pobres encontravam nos legados testamentários um meio para complementar a sua escassa dieta. Ao longo da Idade Média, os mais desfavorecidos eram lembrados com frequência nos testamentos e doações post mortem dos membros poderosos da sociedade, recebendo inúmeras esmolas, que podiam tomar a forma de alimentos ou dinheiro para os adquirir. Deste modo, testadores e doadores contribuíam para o sustento alimentar dos pobres e doentes que gravitariam em torno da igreja ou mosteiro responsável por cumprir a vontade daqueles. Estas doações não eram de todo desinteressadas, cabendo aos seus beneficiários a função de interceder pelos seus benfeitores junto de Deus, através de orações e da sua presença nas missas de sufrágio ${ }^{4}$.

De um total de mais de 180 testamentos e doações de indivíduos de Coimbra ou que beneficiam pessoas e instituições dessa cidade, que contêm legados pios a pobres e/ou estabelecimentos assistenciais, apenas cerca de 40 contemplam os mais necessitados com distribuições de géneros alimentares. De facto, ao contrário do que se verifica noutros países, como em França, em que as esmolas alimentares eram muito frequentes ${ }^{5}$, em Coimbra reparamos que estas ocupam apenas $20 \%$ dos testamentos analisados, estendendo-se até finais do século XIV. No entanto, e excetuando os legados em dinheiro, maioritários, as distribuições de alimentos eram mais comuns do que outros bens doados, como roupa e bens móveis e imóveis ${ }^{6}$. É-nos, pois, possível, a partir dos testamentos analisados, ainda que um pouco lacónicos, tirar importantes conclusões e verificar que, em certos aspetos, a realidade conimbricense se aproximava da realidade além-fronteiras.

A primeira questão que se impõe prende-se com o conhecimento dos pobres a quem o testador de Coimbra dirigia os seus legados de alimentos ${ }^{7}$. De um modo geral, e como temos vindo a afirmar, os principais beneficiados eram os pobres e os doentes. Todavia, tendo em conta que estes dois conceitos se podiam referir a múltiplas situações, na Idade Média, de acordo com a origem da sua pobreza ou a doença de que padeciam, importa esclarecer a quem, especificamente, dirigiam os testadores a sua caridade ${ }^{8}$. A forma mais

${ }^{4}$ Para uma contextualização do papel dos legados pios na salvação da alma e do pobre como intercessor, veja-se Chiffoleau 2011:311-316; Tavares 1989: 80-100; Beirante 2011a: 31-33.

5 Saunier 1993: 29.

${ }^{6} \mathrm{O}$ mesmo se verificaria no Baixo Ródano, tendo em conta que Daniel Le Blévec, ao analisar as aumônes e charités dessa região francesa, afirma que a sua função consistia em distribuir alimentos ou, então, mais raramente, roupas ou dinheiro. Le Blévec 2000: vol. 1, 255.

7 Cf. Gráfico 1. Ver também Anexo 1, onde estão listados os legados analisados e respetivos beneficiários.

8 Sobre o conceito de pobre, veja-se, por todos, Mollat 2006: 9-19. 
comum é o termo pauperes/pobres, referindo-se à massa anónima de indivíduos privados de meios materiais que povoavam a cidade medieval e que encontravam, à porta das igrejas e de instituições caritativas, um contributo para o seu sustento, oferecido em nome daqueles que os pretendiam socorrer. Estaremos, neste caso em concreto, a falar de pobres errantes, não institucionalizados, a quem Jacques Chiffoleau chamou de "pauvres en liberté" . Os leprosos, portadores de uma doença que poderia exigir especiais cuidados com a alimentação, formam outro grupo muito beneficiado com produtos alimentares. Aqui, não podemos afirmar com segurança se, a partir de 1210, data da fundação da Gafaria de Coimbra, quando um testador doava alimentos àqueles doentes se referia aos que habitavam na leprosaria ou aos que nela não tiveram lugar e vagueavam pelas ruas da cidade, sobrevivendo à custa das esmolas que recebiam. Parece mais provável tratar-se destes últimos, pois os que viviam na gafaria dispunham de sustento próprio, embora pudessem receber pitanças ao longo do ano, como iremos ver. Menos abundantes, mas igualmente presentes, eram as doações a cativos (apenas uma), a doentes, sem especificação da sua enfermidade, e, a partir dos finais do século XIII, a pobres envergonhados, aqueles que, descendo na escala social, sentiam vergonha de mendigar. Mais raras vezes ainda, os testadores destinavam legados alimentares a pobres que se encontravam em instituições de assistência da cidade. Mas neste caso referimo-nos a práticas de nutrição em contexto hospitalar, a que voltaremos com mais atenção.

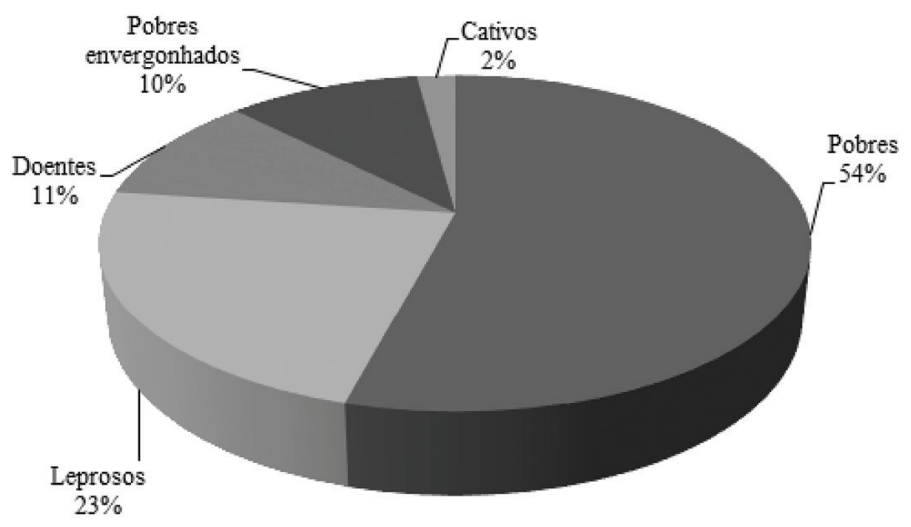

Gráfico 1: Beneficiários dos legados testamentários (séculos XII-XIV)

Integrados na designada "economia da salvação", que consiste numa relação de troca estabelecida entre o rico, doador, e o pobre, beneficiário, pela

\footnotetext{
${ }^{9}$ Chiffoleau 2011: 315.
} 
qual aquele presta socorro a este em troca de benefícios espirituais, os legados de produtos alimentares estavam associados às missas de sufrágio das almas, após a morte do testador, competindo às igrejas onde era realizado o ofício proceder à sua entrega ${ }^{10}$. Os pobres eram, assim, convidados a participar nessas celebrações, na sequência das quais eram repartidas, por aqueles que tivessem estado presentes, determinadas quantidades de pão, vinho e outros alimentos, que podiam, por vezes, assumir a forma de refeições coletivas ${ }^{11}$. Estas distribuições chegavam mesmo a ser normalizadas pelas igrejas onde se praticavam, como aconteceu na de S. Pedro de Coimbra, no ano de 1348, quando, depois da Peste Negra ter dizimado toda a comunidade eclesiástica, o prior, chantre e raçoeiros redigiram novas constituições. Nelas incluiu-se uma cláusula referente às pitanças oferecidas por alma dos defuntos ( $D e p i-$ tanciis que offeruntur per deffunctis), segundo a qual o vinho, a carne e o peixe entregues à igreja, quando eram celebradas missas para os pobres pela alma dos mortos aí sepultados, deviam ser divididos por aqueles que estivessem presentes, para além dos doentes ${ }^{12}$.

As missas de sufrágio e aniversário eram, de facto, uma das principais motivações para a entrega de alimentos aos indigentes que nelas participassem, ainda que essa mesma distribuição não se fizesse logo após a celebração, mas sim noutros dias e contextos. Em Coimbra, mais de metade dos legados estudados surge associada a cerimónias litúrgicas ou com periodicidade estipulada. Encontramos, assim, distribuições que deviam ser feitas aos pobres que fossem às missas encomendadas pelos testadores. Outros testamentos são mais específicos e neles se ordenava que os miseráveis fossem alimentados em dias de sufrágio, entre eles o oitavo dia de soterração, também designado como Sábado, o mês (ou trigésimo) ou o aniversário ${ }^{13}$. Segundo Ângela Beirante, este poderia corresponder ao próprio dia de morte do testador ou a outros dias fixos, em particular festas do calendário litúrgico ${ }^{14}$.

Dos legados analisados, apenas um, registado num livro de aniversários da igreja de Santiago, nos dá uma data certa de celebração do aniversário do

10 Sobre o ofício dos mortos e a distribuição de esmolas aos mais pobres neste contexto, numa paróquia urbana de Coimbra, veja-se Campos 2012: vol. 1, 287-306. Em França e na Catalunha, por exemplo, existiam instituições próprias, anexas às catedrais, responsáveis por dar as esmolas alimentares aos pobres, as designadas aumônes ou charités e almoinas, respetivamente. Cf. Le Blévec 2000: vol. 1, 258-276 e Brodman 1998: 8-14.

11 No conjunto de testamentos analisados, apenas um indica de forma clara que a distribuição seria feita numa refeição para pobres, a realizar três vezes por ano. ANTT, Mosteiro de Santa Cruz de Coimbra, 1 . $^{\text {a }}$ inc., DP, mç. 3, n. ${ }^{\circ}$ 20. Sobre estas refeições colectivas, associadas às cerimónias fúnebres ou realizadas em datas fixas, que podiam ser dirigidas a toda a comunidade ou apenas aos pobres, veja-se Chiffoleau 2011: 142-147; 318-319.

12 ANTT, Colegiada de S. Pedro de Coimbra, liv. 4, fls. 5-5v.

${ }^{13}$ Cf. Anexo 1.

14 Beirante 2011a: 33. 
óbito, 17 de agosto, dia em que os membros da colegiada eram obrigados a vestir, calçar e dar de comer a um pobre, por alma de Fernão Domingues Cornelha, testador, e de sua família ${ }^{15}$. A este soma-se um outro caso, que não temos vindo a considerar no universo de doações pelo seu carácter excecional, em que os dias de refeições a oferecer aos pobres estão bem declarados, sendo mesmo o único em que são discriminadas as principais festas religiosas em que deveriam ter lugar. Trata-se do testamento conjunto do prior D. João Teotónio, dos cónegos de Santa Cruz e do rei D. Afonso Henriques, documento falso, mas com conteúdo real ${ }^{16}$. Segundo este documento, datado de 1166, o convento crúzio obrigava-se a alimentar, no seu refeitório, cem pobres no dia de aniversário da morte do rei e um pobre nas festas mais importantes do calendário litúrgico, a saber, Natal, Última Ceia, Páscoa, Santa Cruz, Pentecostes e Santo Agostinho ${ }^{17}$. Apesar de se desconhecer a sua efetiva aplicação, este testamento permite-nos ter uma ideia de como as refeições coletivas oferecidas aos mais desfavorecidos se podiam distribuir ao longo do calendário.

Para muitos outros legados alimentares, quase metade, desconhecemos quer a data, quer o ritmo com que eram dados aos seus beneficiários. Estaremos, provavelmente, na presença de entregas únicas, a fazer logo após a morte do doador. Não estando associada à celebração de missas de sufrágio, a divisão dos alimentos pelos pobres poderia ser feita na casa do próprio testador, junto da sua sepultura, como observou Jacques Chiffoleau ${ }^{18}$, ou mesmo na igreja ou mosteiro responsável pelo cumprimento dessa cláusula, muitas vezes à sua porta. Foi dessa forma que, em 1356, Sancha Domingues, viúva de João Fernandes Parente, determinou que seriam distribuídos 12 soldos para pão e 8 soldos para vinho pelos pobres na igreja, que presumimos tratar-se da do convento de Santana, referido anteriormente no documento ${ }^{19}$. Um outro exemplo bastante interessante, de que se conhece a data e a periodicidade, é o do testamento de Estêvão Domingues, prior de Serpins, mestre dos órgãos e

15 ANTT, Colegiada de S. Pedro de Coimbra, liv. 1, fl. 4v. Este documento reveste-se também de grande importância por demonstrar que as obrigações associadas aos legados continuavam a cumprir-se passado muito tempo, séculos até, após o testamento. De facto, este livro de aniversários data de 1567 e o testamento de Fernão Domingues Cornelha é anterior a 1332, como prova uma sentença desse ano, em que é referida uma vinha em Almalaguês doada a S. Pedro por aquele testador para que se celebrassem, perpetuamente, o seu aniversário e orações. Varandas 1999: vol. 2, 49.

16 Saul Gomes afirma que este documento é "materialmente falso, mas não quanto ao seu fundamento e realidade histórica” (Gomes 2007: 613). Abiah Reuter já tinha apresentado a mesma ideia, várias décadas antes, no quadro da tradição desse documento, quando o publicou na sua obra Chancelarias Medievais Portuguesas (Reuter 1938: 303).

17 Reuter 1938: 304.

18 Chiffoleau 2011: 143.

19 ANTT, Convento de Santana de Coimbra, mç. 4, s/n (1356 ABRIL 8). 
raçoeiro da igreja de S. Cristóvão, de 1364, em que o testador mandou alguns dos seus herdeiros darem aos pobres, uma vez por ano, no dia dos finados, 20 soldos em pão, vinho e candeias, 15 dos quais seriam distribuídos na igreja de S. Cristóvão, onde o doador seria sepultado, e os restantes 5 soldos seriam levados à igreja de Santa Justa ${ }^{20}$. Além destes, salientam-se ainda outros quatro donativos, de dois testamentos diferentes, que contemplam as donas doentes do mosteiro de Celas da Ponte, ou seja, de Santana, em 1285, e as do mosteiro de Santa Clara, em 1331, a quem as pitanças e frangões doados, resultantes do rendimento de bens imóveis, seriam entregues nos próprios cenóbios, ou melhor, nas suas enfermarias ${ }^{21}$.

Independentemente da regularidade de distribuição de géneros alimentares pelos pobres de Coimbra, estes encontravam nos legados testamentários uma forma de saciar a fome que os atormentaria no seu dia a dia. Neste aspeto, a composição dessas doações desempenhava um papel de relevo. De facto, dependendo da benevolência e capacidade económica dos testadores, quanto mais variados fossem os produtos e quanto maior fosse a sua quantidade, mais rica era a dieta das camadas mais baixas da sociedade.

Do total de doações analisadas, $68 \%$ descreve os alimentos a doar aos mais necessitados, contra $32 \%$ de dádivas em que apenas é declarado que se deve dar de comer a um ou mais pobres ou que se devem estabelecer pitanças ou entregar dinheiro para elas, que, enquanto refeições extra, podiam assumir múltiplas formas. Detendo-nos apenas nos $68 \%$ de legados mencionados, verificamos que $90,6 \%$ deles contemplam pão ou cereais; $46,9 \%$ vinho; $43,8 \%$ carne; e apenas $21,9 \%$ peixe. Note-se que estes produtos podiam ser doados individualmente, ou seja, um tipo de produto por legado, ou então em conjunto, existindo diversas combinações possíveis ${ }^{22}$.

Comecemos pelo pão, produto base da dieta medieval, em conjunto com o vinho, que não podia faltar à mesa de ricos e pobres, sendo mesmo um indicador de hierarquia social ${ }^{23}$. Allen Grieco corrobora esta ideia, ao afirmar que "quanto mais se descia na escala social, mais elevada era a parte representada pelo pão no regime alimentar e, em contrapartida, esta proporção baixava quando se subia na hierarquia social" ${ }^{24}$. Pela sua abundância e variedade, de acordo com a farinha utilizada, de melhor ou pior qualidade, mas também pela sua eficácia no combate à fome, este era, de facto, um dos

20 ANTT, Cabido da Sé de Coimbra, 2. inc., mç. 10, n. ${ }^{\circ} 454$.

${ }^{21}$ TEP: 337-338 e ANTT, Convento de Santa Clara de Coimbra, DP, mç. 19, n.o 30 , respetivamente.

${ }_{22}$ Cf. Anexo 1, onde, de forma sumária, consta a composição de cada legado.

${ }^{23}$ Para uma contextualização da importância do pão na dieta medieval, em particular portuguesa, veja-se Cortonesi 2001: 31-34; Admson 2004: 1-5; Marques 2010: 36-37; Coelho 1990: 10; e Gonçalves 2007.

${ }^{24}$ Grieco 2001: 84. 
principais produtos presentes na nutrição dos mais desfavorecidos. Daí que fosse o género alimentar com maior representação nas doações pias através das quais os pobres de Coimbra, entre os séculos XII e XIV, receberam diversas quantidades de cereal ou dinheiro para o comprar.

Mais de metade dos legados não é muito específica e indica-nos apenas que é doada uma certa quantidade de pão, que poderia corresponder ao cereal em si, um ou mais de entre os panificáveis (trigo, milho, centeio, cevada e aveia), ou ao pão cozido ${ }^{25}$, sem que nos seja possível determinar com clareza ao que se refere, embora seja mais provável tratar-se, na maior parte dos casos, do primeiro ${ }^{26}$. Excetuam-se os testamentos em que é indicado o cereal doado, como veremos, e cinco legados - três de um mesmo testamento - em que sabemos que o trigo ou pão a ser distribuído estava já amassado ou transformado em pão cozido. Em 1296, Pedro Martins, cónego de Coimbra, mandou dar aos pobres presentes no seu trigésimo I modium de farina tritici in pane cocto ${ }^{27}$. Já Domingos António, raçoeiro de Santa Justa, em 1310, e Estêvão Domingues, prior de Serpins, mestre dos órgãos e raçoeiro de S. Cristóvão, em 1364, optaram por fazer em pão ou trigo amassado parte dos seus donativos alimentares ${ }^{28}$.

Embora não sejam maioritárias, as doações em trigo salientam-se no conjunto de legados de pão. Por norma, o pão de trigo, também designado como pão alvo, evocando a cor da sua farinha, cuidadosamente peneirada, estava reservado aos mais ricos. No entanto, nestas dádivas os pobres tinham também acesso ao cereal de primeira. Inclusivamente, em 1310, Domingos António, raçoeiro de Santa Justa, determinou que tanto nas missas do mês, como nas do ano fosse dado aos pobres um moio de bom trigo amassado, confirmando a qualidade do pão que chegava aos mais desfavorecidos ${ }^{29}$. Estando estas distribuições, sobretudo, ligadas às missas de sufrágio, esse seria um privilégio e, acima de tudo, uma recompensa para quem, de entre os indigentes, marcava presença nessas celebrações, contribuindo com a sua intercessão para a salvação eterna do testador. $O$ pão alvo era, pois, nas palavras de Maria Helena da Cruz Coelho, "guloseima de pobres em dias festivos" ${ }^{30}$. Mas não recebiam exclusivamente trigo ou pão de trigo. De facto, os testadores podiam incluir nos seus legados os cereais de segunda, entre

${ }^{25}$ A. H. de Oliveira Marques chama a atenção para a dupla definição do vocábulo "pão" na Idade Média, em particular nas inquirições e forais (Marques 1978: 85-86).

${ }_{26}$ No testamento de Pedro Martins, chantre de Coimbra, de 1322, é claro que o vocábulo panis corresponde ao cereal, pois foi doado o pão de uma herdade em Montemor-o-Velho. TEP: 428.

27 TEP: 359.

28 Campos 2012: vol. 2, 121 e ANTT, Cabido da Sé de Coimbra, 2.a inc., mç. 10, n. ${ }^{\circ}$ 454, respetivamente.

${ }^{29}$ Campos 2012: vol. 2, 121.

30 Coelho 1990: 10. 
milho e centeio, por vezes associados a uma quantidade de trigo, apesar de termos recolhido apenas dois exemplos, para os séculos XII e XIII. Soeiro Tedoniz, em 1135, doou aos pobres dois moios de milho e um de trigo e, por sua vez, Afonso Mendes, em 1240, legou três moios de centeio e dois de trigo, além de carne e vinho, aos pobres presentes nas missas de sufrágio ${ }^{31}$. Através desses dois casos, confirmamos, inegavelmente, que os pobres de Coimbra consumiam o chamado "pão de segunda" ou de "mistura", tão característico dos homens do campo e dos grupos mais desfavorecidos.

Para a maior parte dos casos conhecemos as quantidades de cereal ou dinheiro a ser distribuídas. Verifica-se que estas podiam variar, dependendo da bondade do testador, da sua maior ou menor fortuna, mas também do número de pobres beneficiados, que desconhecemos em todos os exemplos analisados ${ }^{32}$. Esse foi, aliás, um dos principais entraves que encontrámos na nossa investigação, ao impedir-nos de perceber a proporção de cereal doado, ou mesmo de outros alimentos, em relação com o número de pessoas que o consumiam, e se era suficiente ou não para saciar a fome dos pobres de Coimbra. Procurámos, pois, estabelecer comparações com o que se passava noutras cidades europeias, nomeadamente catalãs e francesas, para as quais possuímos mais abundante bibliografia, de modo a tentar perceber quantos indivíduos eram alimentados através destes legados e as quantidades a que tinham acesso. No entanto, a flutuação do número de pessoas assistidas, as condições específicas de cada região, nomeadamente o facto de existirem instituições dedicadas à distribuição de legados alimentares, com uma organização mais formalizada das refeições, não nos permitem tirar conclusões sólidas para o caso de Coimbra ${ }^{33}$. Ainda assim, importa fazer algumas achegas. Apesar dos problemas que se nos colocam, de um modo geral, podemos afirmar que as quantidades apresentam-se relativamente elevadas, podendo

${ }^{31}$ LP: 621 e ANTT, Mosteiro de S. Jorge de Coimbra, 1. a inc., mç. 6, n. 5.

32 A única exceção é o já mencionado testamento feito em conjunto pelo prior de Santa Cruz, pelos seus cónegos e por D. Afonso Henriques, de 1166, no qual se indica que o convento devia alimentar cem pobres no aniversário da morte do rei e um pobre nas principais festas religiosas. Além de não nos ser possível determinar se se tratava de uma medida efetivamente materializada ou apenas simbólica e de consistir numa ação caritativa extraordinária, protagonizada por um dos mais poderosos mosteiros do reino como forma de recompensa pelas inúmeras e generosas doações que o rei lhe fez, quer-nos parecer que estes números estão distantes da média de pobres assistidos através dos legados testamentários de particulares. Reuter 1938: 304.

33 Por exemplo, nas almoinas catalãs, designadamente na de Barcelona, os pobres alimentados por dia podiam rondar os 200. Já no hospital de La Seu d'Urgell eram alimentadas apenas 14 pessoas diariamente. Cf. Brodman 1998: 14-15. Prim Bertran I Roigé, embora demonstre que, no final de 1330, eram alimentados 137 pobres, por dia, na almoina da catedral de Lleida e, em 1338, cerca de 90, afirma que as quantidades de pão oferecidas eram suficientes para alimentar 10 a 15 pobres, um número que nos parece um pouco mais próximo do que seria a realidade em Coimbra. Bertran i Roigé 1979: 93-94; 96. 
algumas ultrapassar, em medidas atuais, os $1000 \mathrm{~kg}$ de cereal por distribuição. Tomemos como exemplo os testamentos de D. Ximena Forjaz e João Gosendes, casados, ambos de 1110, e nos quais são atribuídas as mesmas quantidades de cereal e vinho. Tanto um doador como o outro legou 15 moios entre pão e vinho a pobres, no dia de aniversário do seu óbito ${ }^{34}$. Neste caso, tal como na maior parte, não sabemos por quantos indivíduos foram divididos estes moios, nem a quantidade certa de cada um dos géneros doados. Ainda assim, quer-nos parecer que as quantidades rondariam as consideradas normais numa época de elevado consumo de pão, em que, no século XIII, segundo a lei de almotaçaria, os trabalhadores rurais consumiam, em média, $800 \mathrm{~g}$ de pão por $\operatorname{dia}^{35}$.

Noutros exemplos, em que é possível discriminar a quantidade de pão doada, mesmo que o legado seja composto por outros produtos, torna-se mais fácil estabelecer algumas hipóteses. Para isso, selecionámos, como amostra, um testamento de cada um dos séculos em estudo. No século XII, em 1135, o presbítero Soeiro Tedoniz doou dois moios de milho e um de trigo, que correspondem, na medida atual, a cerca de $1280 \mathrm{~kg}$ e $640 \mathrm{~kg}$, respetivamente ${ }^{36}$. Mais tarde, já no final do século seguinte, em 1296, Pedro Martins, cónego da Sé, fez dois diferentes legados alimentares aos pobres, um a distribuir no Sábado da sua morte e o outro no trigésimo dia. Assim, seriam doados três quarteiros de farinha de trigo (cerca de $480 \mathrm{~kg}$ ) naquele dia e um moio de farinha de trigo em pão cozido (cerca de $640 \mathrm{~kg}$ ) no último ${ }^{37}$. Sabendo nós, como já o afirmámos, que, no século XIII, o homem do campo medieval consumia, em média, $800 \mathrm{~g}$ de cereal diariamente, parece-nos provável que se poderia, com as quantidades doadas, alimentar à volta de duas ou três dezenas de pobres durante cerca de um mês ou mais. No entanto, reforçamos a ideia de que estamos na presença de hipóteses dependentes de muitas variáveis. Daniel Le Blévec alerta para estes perigos ao tentar definir quantas pessoas beneficiavam da esmola do pão em Nîmes, pois não é possível saber como era composta uma ração individual ${ }^{38}$.

O século XIV, por sua vez, apresenta algumas alterações. Os legados de pão eram, sobretudo, feitos em dinheiro e algumas quantidades atribuídas, tanto nesta forma como em géneros, parecem-nos meramente simbólicas. Em 1356, Sancha Domingues doou 12 soldos para pão, a dar aos pobres

${ }^{34}$ LP: 68; 364.

35 Coelho 1990: 15.

${ }^{36}$ LP: 621. Em Coimbra, na Idade Média, um alqueire equivalia a $10 \mathrm{~kg}$, logo um moio (64 alqueires) equivalia a $640 \mathrm{~kg}$. Para estabelecer as equivalências entre as medidas medievais e as de hoje, recorremos a Coelho 1990: 18, n. 8. Ver também Marques 1985: 70-72.

37 TEP: 359 . Um quarteiro correspondia a 16 alqueires, ou seja, a $160 \mathrm{~kg}$ em medida atual. Sobre a conversão de medidas, veja-se, acima, a nota 36 .

38 Le Blévec 2000: vol. 1, 272-273. 
na igreja do mosteiro de Santana de Coimbra ${ }^{39}$. Admitindo que se trata de trigo e tendo em conta que o preço do alqueire desse cereal, por esta altura, rondava em Coimbra os 20 soldos, essa soma apenas permitia comprar 0,6 alqueires, que equivale a cerca de $6 \mathrm{~kg}$ de trigo, uma pequena quantidade de cereal a distribuir por vários pobres ${ }^{40}$. Estêvão Domingues, o já referido prior de Serpins, mestre dos órgãos e raçoeiro da igreja de S. Cristóvão, legou em 1364 um quarteiro de trigo amassado (cerca de $160 \mathrm{~kg}$ ) aos pobres, a dar no oitavo dia do seu enterramento. Além disso, Vasco, Fernando e Irene, herdeiros de algumas das suas propriedades, ficavam obrigados a dar aos pobres, anualmente, no dia de finados, 20 soldos em pão, vinho e candeias, a saber, 15 soldos a entregar em S. Cristóvão, local de sepultura do testador, e 5 soldos em Santa Justa, legado já aqui analisado a propósito do local de distribuição ${ }^{41}$. Com estas duas doações de Estêvão Domingues não seria possível alimentar um número muito elevado de pobres durante um período de tempo relativamente longo, como vimos acima. De qualquer forma, os mais desfavorecidos contavam com estes pequenos donativos para comer algum pão, alimento rico em hidratos de carbono e indispensável na dieta medieval.

O vinho, como já vimos, ocupava, ao lado do pão, um lugar fundamental na dieta mediterrânica medieval, em geral, e na dos pobres, em particular. É, inclusive, muito frequente surgirem associados, como acontece nos testamentos da sociedade conimbricense, em que todas as doações de vinho incluem também pão ${ }^{42}$. Esta observação leva-nos a concluir que a associação entre estes dois produtos nas doações testamentárias, quase sempre ligadas à celebração de missas de sufrágio, tem, acima de tudo, um valor simbólico, representando o corpo e sangue de $\mathrm{Cristo}^{43}$. De resto, à parte a sua simbologia, numa época em que a água potável escasseava, a população recorria ao vinho para acompanhar as refeições, mas também para saciar a sede ${ }^{44}$.

A análise das distribuições de vinho pelos pobres apresenta os mesmos entraves que a do pão. Aqui ainda acresce o facto de só conhecermos quantidades e quantias em dinheiro exatas para muito poucos legados, impossibilitando-nos de estabelecer padrões. Salientem-se três doações de que se conhecem as quantidades a oferecer aos pobres presentes nas celebrações fúnebres ordenadas pelos testadores. Em data incerta, Martim Domingues mandou dar, para além de pão e carne, um quinal de vinho aos pobres que

\footnotetext{
39 ANTT, Convento de Santana de Coimbra, mç. 4, s/n (1356 ABRIL 8).

40 Recolhemos a informação dos preços do trigo em Marques 1978: 220-222.

${ }^{41}$ ANTT, Cabido da Sé de Coimbra, 2. ${ }^{\mathrm{a}}$ inc., mç. 10, n. ${ }^{\circ} 454$.

${ }^{42}$ Cf. Anexo 1.

${ }^{43}$ Cf. Montanari 1993: 26-30; Gonçalves 2010: 226.

${ }^{44}$ Cf. Coelho 1990: 11 e Adamson 2004: 48 e 49-51.
} 
estivessem nas missas, o que equivaleria a cerca de $425 \mathrm{l}^{45}$. Por sua vez, no século XII, em 1130, Maria Peres destinou dois quinais desta bebida para os pobres que fossem às suas missas, ou seja, cerca de $8501^{46}$. Cerca de um século mais tarde, em 1240, Afonso Mendes doou dois moios de vinho, mais uma vez, aos pobres presentes nas missas, o que significa que estes receberiam cerca de 6801 da bebida medieval por excelência ${ }^{47}$. Para além de ficarmos a conhecer os valores exatos de vinho atribuídos aos miseráveis de Coimbra em três datas diferentes, estes legados não nos permitem tirar outras conclusões, pela ausência de termos que facilitem a comparação, como, por exemplo, o número de indivíduos beneficiados, para podermos fazer uma média de consumo individual, e o período de tempo em que era consumido. Mas parece natural que, uma vez que o vinho era doado em conjunto com o pão, a sua quantidade fosse proporcional à de cereal e, como já vimos, este seria suficiente para alimentar vários pobres durante um largo período de tempo. Note-se, todavia, que, salvo algumas exceções, sabemos através de alguns documentos que haveria preocupação em fornecer vinho em grandes quantidades, como se verifica no testamento conjunto de Rodrigo Pais e Elvira Rabaldes, sua mulher, em que ambos, em legados separados, determinaram que fosse dada uma refeição aos pobres, três vezes por ano, na qual se deveria gastar, entre outras coisas, pão e vinho em abundância ${ }^{48}$.

Por vezes, as refeições oferecidas aos pobres eram ainda enriquecidas com carne e peixe. Estes produtos, o designado conduto, por servirem para acompanhar o pão e vinho, eram muito pouco acessíveis aos mais desfavorecidos, pelo que constituíam um privilégio daqueles que assistiam à celebração de aniversários de óbito e que tinham por missão auxiliar o rico na busca da salvação eterna. Nos testamentos de Coimbra, a doação de carne aos pobres não tem uma representação tão significativa como o pão, apesar de ser também uma das bases da alimentação medieval, mas, ainda assim, é referida em mais de $40 \%$ dos legados, tanto na forma de dinheiro para a comprar, como na quantidade de tipos de carne a distribuir ${ }^{49}$.

Logo a partir do século XII, os testadores conimbricenses incluíram a carne nos donativos alimentares, registando-se um aumento nos finais do século XIII. Quando discriminada a variedade a doar, a opção recaía sobre

45 ANTT, Mosteiro de Santa Cruz de Coimbra, 1. ${ }^{a}$ inc., DP, mç. 14, n. ${ }^{\circ} 36$. Um quinal equivalia a 25 almudes. Uma vez que, em Coimbra, um almude valia 171 , um quinal eram 4251 . Cf. Coelho 1990: 18, n. 7 e Marques 1985: 69-70.

${ }^{46}$ ANTT, Mosteiro de Santa Cruz de Coimbra, $1 .^{\mathrm{a}}$ inc., DP, mç. 5, n. ${ }^{\circ} 2$.

47 ANTT, Mosteiro de S. Jorge de Coimbra, $1 .^{\mathrm{a}}$ inc., mç. 6, n. ${ }^{\circ}$ 5. Segundo Oliveira Marques, um moio, enquanto medida de capacidade, equivalia a 20 almudes. Deste modo, para Coimbra, um moio de vinho valia 340 1. Marques 1985: 70.

48 ANTT, Mosteiro de Santa Cruz de Coimbra, 1. ${ }^{\mathrm{a}}$ inc., DP, mç. 3, n. ${ }^{\circ} 20$.

${ }^{49}$ Cf. Anexo 1. 
as espécies mais comuns da dieta medieval, ou seja, as mais gordas, como a vaca e o carneiro, sem esquecer, mais raras vezes, o porco ${ }^{50}$. Atendendo aos banquetes oferecidos pelas confrarias medievais, os dois primeiros eram, de facto, muito comuns, como demonstra Ângela Beirante, o que nos mostra que seria uma carne, por vezes, destinada aos pobres, que eram uma presença assídua nestas refeições coletivas ${ }^{51}$. Adeline Rucquoi confirma o consumo de carneiro por estes indivíduos, afirmando que este, ao constar na lista de compras da Confraria de Todos os Santos, de Valladolid, no século XV, era a "carne tradicionalmente reservada aos pobres" ${ }^{2}$. A inclusão desta carne na dieta dos mais necessitados em Coimbra, no século XII, adquire, no entanto, outro relevo, pois era uma das mais apreciadas e caras, segundo as posturas desta cidade, de $1145^{53}$. O carneiro em conjunto com a vaca foram as carnes escolhidas pelos testadores mais generosos. De facto, em 1149, o casal Rodrigo Pais e Elvira Rabaldes, a que já aludimos, mandou que se gastasse, em cada uma das três refeições anuais destinadas aos pobres, duas vacas e vinte carneiros ${ }^{54}$. Mais tarde, já no século seguinte, Afonso Mendes legou duas vacas e doze carneiros, uma quantidade inferior mas também significativa ${ }^{55}$.

Por fim, não podemos deixar de mencionar a quase ausência de aves de capoeira. Não excluindo a hipótese de a carne de aves compor os legados em que é apenas indicado, de forma geral, que é doada "carne", as donas doentes do mosteiro de Santana foram as únicas beneficiadas com frangões, em 1331, por Joana Gonçalves Redonda ${ }^{56}$. Esta dádiva compreende-se facilmente pelas qualidades terapêuticas da carne de aves, magra e de fácil digestão, que fazia delas os "animais por excelência próprios dos doentes" 57 .

O peixe, por sua vez, é muito mais raro na documentação analisada, apesar da sua abundância em território português, em geral, e na zona de Coimbra, em particular. Extremamente variado, encontrava-se à venda nesta cidade tanto peixe do mar como do rio, chegando nas suas múltiplas formas às mesas dos mais abastados e, em menor dose e variedade, às dos mais desfavorecidos ${ }^{58}$. Mesmo em quantidades reduzidas, os pobres não eram exceção e, por vezes, eram beneficiados com dinheiro para adquirir este alimento tão saudável.

50 Em Portugal consumia-se uma larga variedade de carnes, entre as ditas de matadouro, carnes mais gordas, as de caça e as de criação, não muito diferentes das que se comem hoje em dia. Cf. Marques 2010: 28-29.

${ }^{51}$ Beirante 2011b: 190.

52 Rucquoi 1984: 301.

53 Coelho 2013: 37. Cf. Coelho 1990: 11.

${ }^{54}$ ANTT, Mosteiro de Santa Cruz de Coimbra, 1. ${ }^{\mathrm{a}}$ inc., DP, mç. 3, n. ${ }^{\circ} 20$.

55 ANTT, Mosteiro de S. Jorge de Coimbra, $1 .^{\mathrm{a}}$ inc., mç. 6, n. ${ }^{\circ} 5$.

56 ANTT, Convento de Santa Clara de Coimbra, DP, mç. 19, n. 30.

57 Bertran i Roigé 1979: 101. Cf. Adamson 2004: 34.

${ }^{58}$ Cf. Coelho 1990: 11. Sobre as variedades de peixe em Portugal, na Idade Média, e a sua importância à mesa, veja-se Marques 2010: 30-31 e Gomes 2011: 34-44; 75-95. 
A escassez de informação nos legados por nós analisados não nos permite extrair conclusões como as que tirámos para os outros géneros. No entanto, sabendo que o consumo deste alimento aumentava em épocas de jejum e abstinência impostas pela Igreja, como era o caso da Quaresma, temos duas doações a leprosos que poderão indicar precisamente esta utilidade do peixe ${ }^{59}$. Com efeito, o cónego Martim Martins legou um morabitino para peixe aos leprosos, em março de 1220 , mês em que se celebrou a Páscoa nesse $a n o^{60}$. Mais tarde, no mesmo século, em 1292, o cavaleiro Martim Esteves beneficiou os gafos de Coimbra com 20 soldos para peixe e as donas do Hospital de Santa Cruz com uma libra para o mesmo fim $^{61}$. Este testamento foi elaborado no dia 16 de fevereiro, muito próximo de dia 20, início da Quaresma naquele ano ${ }^{62}$. Todavia, as restantes doações de peixe foram feitas em datas afastadas desta época de jejum e, quase sempre, em conjunto com outros géneros, o que poderá significar apenas um enriquecimento da dieta dos pobres com os nutrientes, como a proteína, o fósforo e a vitamina $\mathrm{C}$, que tão rico alimento proporcionava.

Como vimos, as refeições dos indivíduos que compunham os estratos mais baixos da sociedade medieval eram muito monótonas e compostas essencialmente por pão e vinho, acompanhados, por vezes, de carne e peixe. Notamos a ausência de produtos imprescindíveis, como os legumes e a fruta, que, pela sua riqueza nutricional, dariam àqueles homens famintos uma dieta muito mais equilibrada. Mas não podemos deixar de salientar, apesar de tudo, a importância destas doações para quem nada tinha. De facto, através dos legados esporádicos de produtos alimentares e refeições coletivas, os pobres da cidade do Mondego acediam a uma parte das calorias diárias e nutrientes necessários ao bom funcionamento do seu organismo e que contribuiriam para uma melhoria das suas condições de vida e, ainda que ligeiramente, para o combate à fome.

${ }^{59}$ As constituições sinodais portuguesas contêm várias normas relativas à prática do jejum, nomeadamente os dias em que devia ser respeitado. Vejam-se, por exemplo, as listas de festas que se deviam guardar e em que se devia jejuar de acordo com dois sínodos do século XV, em Garcia y Garcia 1982: 403-405; 440-441. Guida da Silva Cândido analisa, num artigo recente (Cândido 2014), a problemática das restrições e recomendações alimentares resultantes dos sínodos portugueses.

${ }^{60}$ TEP: 248. Recolhemos a informação relativa à celebração da Páscoa em Cappelli 1988: 50.

${ }^{61}$ ANTT, Mosteiro de Santa Cruz de Coimbra, 2. ${ }^{\mathrm{a}}$ inc., mç. 4, "Alm. 11, n. ${ }^{\circ} 27$, mç. 6".

${ }^{62}$ Cappelli 1988: 66. 


\section{Alimentar os pobres e doentes em contexto institucional}

Em franca expansão a partir do século XII, as instituições caritativas ofereciam também, a par dos legados testamentários e muitas vezes beneficiando deles, assistência alimentar aos pobres e doentes. Por um lado, entre essas instituições contam-se as confrarias, associações de solidariedade horizontal que previam a assistência mútua entre os seus confrades, mas que não excluíam dos seus compromissos e atividade o socorro aos mais desfavorecidos ${ }^{63}$. Por outro, temos as albergarias e hospitais - entre os quais as gafarias - que acolhiam os indigentes e enfermos que necessitassem de uma cama e teto para passar algumas noites, podendo ser de fundação privada, através do testamento, ou estar ligados a uma confraria ou mesmo a um mosteiro. As suas funções passavam por oferecer "acolhimento, roupas, alimentação, água e lume” ${ }^{64}$. Eram, pois, uma das formas de materialização da caridade e das obras de misericórdia, nomeadamente a que consiste em alimentar os famintos ${ }^{65}$.

Comecemos pelas primeiras, as confrarias. Uma das práticas de sociabilidade mais importantes destas associações era a realização de refeições comunitárias, um momento de convívio que reunia à volta da mesa os confrades e que se revestia de um carácter sagrado. Não raras vezes, os compromissos estipulavam que estas refeições deviam também integrar pobres, que assumiam aqui o papel simbólico do irmão defunto ${ }^{66}$. Em Coimbra, poucas são as confrarias que contemplam nos seus compromissos a assistência alimentar aos mais necessitados. Referimo-nos à Confraria de S. Nicolau, com estatutos do século XII (1144), e à de S. Marcos, cujo compromisso data de 1290. Podemos aqui acrescentar o exemplo da Confraria de Santa Maria da Vera Cruz, que, nos inícios do século XVI, dava três alqueires de pão amassado aos pobres fora do contexto das refeições coletivas, como se presume pela leitura do documento ${ }^{67}$. $\mathrm{Na}$ Confraria de S. Nicolau, aqueles tinham lugar à mesa, representando os irmãos falecidos, como o compromisso nos mostra claramente: "e saibam aquelles a que he abastamça de riqueza quando vier a comer por cada huum dos seus irmãaos finados tamtos pobres tragam aa mesa e os fartem" ${ }^{68}$. No final do banquete, os indigentes tinham ainda direito

63 Não pretendendo ser demasiado exaustiva, para uma descrição e contextualização das confrarias medievais portuguesas, citem-se, por exemplo, Beirante 1990 e Coelho 1992.

64 Tavares 1989: 126.

65 A bibliografia sobre hospitais medievais é muito abundante e o tema continua a despertar o interesse dos historiadores. Aconselha-se, para esclarecimento do conceito de hospital e albergaria na Idade Média, a leitura de Horden 1988; Rubin 1991; e Tavares 1989: 124-145.

${ }_{66}$ Cf. Beirante 2011b: 188-189 e Coelho 1992: 166-167.

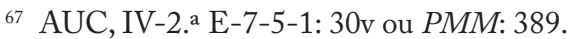

68 AUC, IV-2. ${ }^{\mathrm{a}} \mathrm{E}-7-5-1: 92 \mathrm{v}$ ou PMM: 266. 
a tudo o que sobrasse e ficasse na mesa. O compromisso não nos informa sobre os alimentos que se disporiam nela, mas, tomando como exemplo outras confrarias, o repasto incluiria, por certo, o pão, o vinho e o conduto, que seria sobretudo carne, nomeadamente de porco, vaca e carneiro, muito apreciadas nestas refeições ${ }^{69}$. $\mathrm{Na}$ Confraria de $\mathrm{S}$. Marcos, cujo compromisso não é muito mais esclarecedor, realizava-se uma colação em honra do santo da sua invocação, da qual os pobres recebiam uma parte. De facto, no final do jantar, depois de os mordomos saírem, era-lhes dada a terça parte do pão, juntamente com o conduto que sobrasse ${ }^{70}$. Os mais desfavorecidos tomavam assim parte de refeições reservadas aos confrades, desempenhando mesmo um papel positivo na sociedade, pela carga simbólica que lhes era atribuída, além da oportunidade que tinham de saciar a sua fome.

Fundados por particulares, através dos seus testamentos, ou anexos às confrarias, os hospitais ou albergarias incluiriam entre as suas funções garantir alimentação e, sobretudo, bebida aos seus habitantes. $\mathrm{Na}$ sua maioria de reduzidas dimensões e de magras rendas, estes estabelecimentos não estariam devidamente dotados para proporcionar aos pobres, peregrinos e doentes que os procuravam uma dieta rica e equilibrada, estando aptos apenas para suprir as necessidades mais básicas. Além disso, estariam muitas vezes dependentes da generosidade dos seus fundadores ou de outros benfeitores, integrando os legados pios dos seus testamentos e doações. Não obstante, algumas fontes fornecem-nos dados que nos permitem percecionar como se provia o sustento alimentar nestas instituições.

Antes de mais, as informações recolhidas demonstram que, nos hospitais, a variedade de géneros é ainda menor do que a oferecida em legados testamentários. O pão e o cereal, como sempre, eram presença assídua. Em 1310, Domingos António doou um alqueire de bom milho, cerca de $10 \mathrm{~kg}$ pela medida de Coimbra ${ }^{71}$, a cada morador das suas albergarias que fosse à sua sepultura e lhe fizesse companhia no dia de enterro e no dia ou noite em que morresse $\mathrm{f}^{72}$. Mais uma vez, esta doação é uma recompensa pelas funções espirituais que os pobres deviam cumprir, ao acompanhar o seu benfeitor, fundador de um lugar onde encontravam conforto e comida, na hora da morte, fazendo-nos lembrar as obrigações dos confrades para com os seus irmãos, numa confraria. Ao pão podia somar-se a carne. Por exemplo, o cónego João Gomes beneficiou, no ano de 1322, os mosteiros, emparedadas, pobres envergonhados e albergarias de Coimbra com 15 libras em pão e carne de porco, por alma de Domingos Eanes, antigo chantre de S. Pedro de

\footnotetext{
69 Beirante 2011b: 189-190.

70 AUC, IV-2.a E-7-5-1: 79-79v ou PMM: 316.

${ }^{71}$ Como já vimos anteriormente, na cidade de Coimbra, o alqueire valia $10 \mathrm{~kg}$. Cf., acima, n. 37 .

${ }^{72}$ Campos 2012: vol. 2, 120.
} 
Almedina ${ }^{73}$. Esta seria uma boa oportunidade para os pobres e doentes dos hospitais da cidade consumirem alguma proteína.

Maior relevo assumem as referências aos caldos, apesar de se resumirem a duas. Maria Geraldes, merceeira, moradora em Coimbra, senhora de grande devoção e benfeitora dos mais desfavorecidos, ao doar, em 1367, a terça parte de um casal acima de Ega (fr., c. Condeixa-a-Nova) à sua criada e seus sucessores, deixou claro que, se as cláusulas do legado não fossem cumpridas, essa terça parte seria dada à Confraria de Santa Cruz para caldo para os enfermos ${ }^{74}$. No final da década seguinte, em julho de 1379, o cabido da Sé de Coimbra emprazou, a João Eanes de Sousa e a sua mulher, a Albergaria de Santa Maria, com a obrigação de repararem as suas casas e prestarem assistência aos pobres e doentes que aí procurassem abrigo. O documento é claro: "que tenham hi senpre da agua pera os pobres e que outrossi se amerceem dos pobres que hi adoecerem visitando os e dando lhi do caldo da farinha"75. Por norma, os hospitais medievais não ofereciam cuidados médicos aos seus "hóspedes", mas nestas duas referências encontramos, ao contrário de todas as anteriores, algumas preocupações terapêuticas ${ }^{76}$. De facto, sobretudo no último exemplo, vemos que mais nenhum alimento é descrito, a não ser o caldo de farinha a dar aos doentes ${ }^{77}$.

$\mathrm{Na}$ vasta rede hospitalar de Coimbra na Idade Média, sobressaem dois casos para os quais a informação acerca das dietas a praticar é mais rica. Referimo-nos ao Hospital de Santa Isabel e ao Hospital de S. Lázaro, destinado a quem sofria de lepra. Sendo estes os únicos hospitais de Coimbra que normalizaram a dieta dos seus habitantes, das mais ricas e variadas da cidade, importa fazer uma análise comparativa.

$\mathrm{O}$ primeiro foi fundado pela rainha $\mathrm{D}$. Isabel, no codicilo ao seu testamento, de 12 de março de 1328, no qual foram fixadas as normas de administração do novo hospital, sediado no paço da rainha, junto do mosteiro de Santa $\mathrm{Clara}^{78}$. Entre essas normas contam-se as de provimento alimentar dos 30

73 TEP: 444.

74 ANTT, Convento de Santana de Coimbra, mç. 4, s/n (1367 OUTUBRO 18).

75 ANTT, Cabido da Sé de Coimbra, 2. ${ }^{a}$ inc., mç. 74, n. 2966.

76 À exceção destes dois exemplos, para o caso de Coimbra, ainda não encontrámos na investigação que temos vindo a desenvolver referências relevantes ao recurso a práticas médicas nos hospitais da cidade. Sobre os cuidados terapêuticos oferecidos num hospital medieval inglês, veja-se Rawcliffe 1999: 159-176.

77 Desde sempre, os caldos, entre eles os de farinha, foram alimento de eleição para os enfermos, pela sua simples composição e facilidade de digestão. Embora muito mais tardios do que as fontes aqui analisadas, foram, recentemente, publicados dois receituários conventuais setecentistas em que é clara a utilização dos caldos no tratamento de doentes. Braga 2015: 46; 132-134.

${ }_{78}$ Entre os autores mais recentes que nos oferecem uma perspetiva da fundação e papel do Hospital de Santa Isabel na Idade Média, podemos citar Francisco Pato de Macedo (Macedo 2000). 
pobres envergonhados (15 homens e 15 mulheres) que o hospital estava apto a receber. A descrição da dieta é sucinta e, em termos de variedade, pouca novidade nos traz em relação ao consumo alimentar dos pobres na cidade de Coimbra que temos vindo a mostrar. No entanto, o ponto forte deste exemplo é o conhecimento das rações individuais, que permite calcular o seu consumo diário $^{79}$. Deste modo, cada pobre do Hospital de Santa Isabel ou Elisabete, como o nomeou a rainha no seu testamento, recebia, diariamente, 32 onças de pão cozido, uma tagra de vinho, dois arráteis de carne, que podia ser carneiro, porco ou vaca, e uma quantidade de pescado determinada pela abadessa, em dias de jejum ${ }^{80}$. Isto significa um consumo individual de, aproximadamente, $918 \mathrm{~g}$ de pão, uma média de 21 de vinho e $918 \mathrm{~g}$ de carne ${ }^{81}$. Segundo os cálculos de Maria Helena da Cruz Coelho, estes indivíduos ingeriam entre 4356 e 5520 calorias diárias ${ }^{82}$. Em resumo, os pobres envergonhados do Hospital de Santa Isabel tinham uma dieta rica em proteína e hidratos de carbono, em doses muito próximas, muito calórica, mas pobre em vitaminas e outros nutrientes.

\begin{tabular}{|c|c|c|c|}
\hline Géneros alimentares & Quantidade & $\begin{array}{c}\text { Medidas } \\
\text { atuais }\end{array}$ & $\begin{array}{l}\text { Calorias } \\
\text { diárias }\end{array}$ \\
\hline Pão cozido & 32 onças & $918 \mathrm{~g}$ & \multirow{4}{*}{$4356-5520$} \\
\hline Vinho & 1 tagra & $1,41-2,61$ & \\
\hline Carne (caneiro, porco ou vaca) & 2 arráteis & $918 \mathrm{~g}$ & \\
\hline Pescado & Indeterminado & - & \\
\hline
\end{tabular}

Tabela 1: Ração individual dos pobres do Hospital de Santa Isabel (1328) ${ }^{83}$

Foquemo-nos agora no outro exemplo, o Hospital de S. Lázaro de Coimbra, extremamente rico no que respeita a dados sobre a alimentação dos leprosos na Idade Média portuguesa. Fundado em 1210 pelo rei D. Sancho I, este hospital recebeu o seu primeiro regimento mais de um século depois, em 1329, pela mão de $\mathrm{D}$. Afonso IV, que regulamentou todo o quotidiano da instituição, dando particular ênfase à composição do provento dos leprosos e

79 Não nos deteremos demasiado sobre a dieta dos pobres do hospital da rainha D. Isabel, pois os resultados da sua análise foram já apresentados por Maria Helena da Cruz Coelho, em Coelho 1990: 14.

80 PMM: 507.

${ }^{81}$ Em Coimbra, uma onça equivalia a 28,7 g, o arrátel a 459 g e uma tagra podia variar entre 1,4 1 e 2,6 1. Cf. Coelho 1990: 20, n. 36 e 37.

82 Coelho 1990: 14. Ver Tabela 1.

83 Essa tabela foi elaborada com base no codicilo ao testamento de D. Isabel, de 1328 (PMM: 507), e na já referida análise de Maria Helena da Cruz Coelho (Coelho 1990: 14). 
"Dar de comer a quem tem fome": a dieta alimentar dos pobres e doentes de Coimbra na Idade Média

dos merceeiros sãos, pobres envergonhados que aqui recebiam o seu sustento ${ }^{84}$. Embora as fontes existentes nos permitam traçar os hábitos alimentares dos gafos e merceeiros ao longo de toda a Idade Média, deter-nos-emos apenas no referido regimento, para apresentar uma perspetiva da dieta diária de um grupo muito específico de doentes no século XIV, de modo a ser possível estabelecer uma comparação com o exemplo anterior ${ }^{85}$. Para uma melhor perceção do regime alimentar oferecido na Gafaria de Coimbra, dispusemos os dados recolhidos na tabela que se segue.

\begin{tabular}{|c|c|c|c|c|c|c|}
\cline { 2 - 7 } \multicolumn{1}{c|}{} & \multicolumn{3}{c|}{ Leprosos } & \multicolumn{3}{c|}{ Merceeiros sãos } \\
\cline { 2 - 7 } \multicolumn{1}{c|}{} & Diária & Anual & $\begin{array}{c}\text { Média diária } \\
(\mathrm{kg} \text { ou } 1)\end{array}$ & Diária & Anual & $\begin{array}{c}\text { Média diária } \\
(\mathrm{kg} \text { ou 1) }\end{array}$ \\
\hline Trigo & - & 2 moios & $3,5 \mathrm{~kg}$ & - & 1 moio & $1,75 \mathrm{~kg}$ \\
\hline $\begin{array}{c}\text { Cereal de } \\
\text { segunda }\end{array}$ & - & 2 quarteiros & $0,9 \mathrm{~kg}$ & - & 6 quarteiros & $2,63 \mathrm{~kg}$ \\
\hline Vinho & 1,5 meias & - & 31 & 1,5 meias & - & 31 \\
\hline Azeite & - & 1 alqueire & 0,051 & - & - & - \\
\hline Sal & - & 1 alqueire & $0,03 \mathrm{~kg}$ & - & - & - \\
\hline
\end{tabular}

Tabela 2: Rações individuais dos leprosos e merceeiros sãos do Hospital de S. Lázaro (1329)

Como podemos ver, a partir de 1329, cada leproso de S. Lázaro de Coimbra passou a ter direito a um provento anual composto por dois moios de trigo (ou, quando este faltasse no celeiro, quatro quarteiros de segunda), dois quarteiros de cereal de segunda, a que se acrescentava uma meia e meia de vinho, por dia, e um alqueire de azeite e outro de sal, no primeiro dia de janeiro ${ }^{86}$. Convertendo para as medidas atuais, isto significa que caberia a cada gafo de Coimbra, em média, cerca de $5 \mathrm{~kg}$ de cereal e 31 de vinho, por dia $^{87}$. Estas são quantidades que se distinguem claramente das que aqui

${ }^{84}$ Sobre a fundação, evolução e funcionamento do Hospital de S. Lázaro, veja-se Rocha 2011: 44-79.

${ }^{85}$ É nosso objetivo apresentar apenas a ração-base de cada leproso e merceeiro são, em 1329, para podermos comparar com o caso do Hospital da rainha D. Isabel. Deste modo, não serão abordadas as pitanças distribuídas ao longo do ano, nem a evolução das quantidades atribuídas a cada doente até aos inícios do século XVI, uma vez que já analisámos estas questões na nossa dissertação de mestrado (Rocha 2011: 71-76). Entretanto, publicámos um artigo inteiramente dedicado ao tema (Rocha 2016).

86 AUC, Cofre 34: 1 ou Rocha 2011: 157.

87 Chegámos a estes valores através da conversão da quantidade anual de cereal para medidas atuais, dividindo esse total pelos 365 dias de um ano comum. Um moio correspondia a 64 alqueires $(640 \mathrm{~kg})$, tal como já afirmámos atrás, e um quarteiro a 16 alqueires, ou seja, $160 \mathrm{~kg}$. No caso do vinho, como se verifica, não houve necessidade de proceder à mesma divisão, uma vez que era entregue diariamente aos doentes. Esclareçamos apenas que uma meia equivalia a 
temos apresentado para outros casos, em particular as que eram entregues aos pobres envergonhados do hospital da rainha D. Isabel, muito inferiores. Inclusivamente, estes valores são muito superiores aos das gafarias da província francesa de Sens, onde o consumo diário individual rondava $1 \mathrm{~kg}$ de pão por dia, no século XIV ${ }^{88}$. De facto, mesmo numa época de elevado consumo de pão, todo aquele cereal que os gafos de S. Lázaro recebiam parece-nos excessivo, o que nos leva a considerar que este não seria todo para seu consumo pessoal. As fontes parecem confirmar esta aceção. Em 1454, numa carta de D. Afonso $V$, são mencionadas as vendas anuais dos moios, no hospital, nas quais seria vendido o cereal resultante das rendas, mas talvez também aquele que cada doente recebia a mais, embora nesta altura as rações individuais já fossem um pouco menores ${ }^{89}$.

Não podemos deixar de fazer menção ao azeite e sal atribuído a cada leproso e que davam um gosto diferente às suas refeições. Note-se que em nenhum outro hospital da cidade os pobres ou doentes recebiam tais produtos. As refeições dos gafos eram ainda enriquecidas com uma grande variedade de produtos, entre os quais a carne e fruta, entregues ao longo do ano, sob a forma de pitanças ${ }^{90}$.

Por sua vez, os merceeiros sãos recebiam uma ração alimentar inferior aos leprosos, talvez por não terem as mesmas necessidades nutricionais que estes, tendo em conta a sua patologia. Assim, cada são tinha direito a um moio de trigo e seis quarteiros de cereal de segunda, por ano, e a mesma quantidade diária de vinho que cada leproso, ou seja, uma meia e meia de vinho ${ }^{91}$. Isto significa que, diariamente, estes pobres tinham acesso a, aproximadamente, $1,75 \mathrm{~kg}$ de trigo, 2,63 kg de cereal de segunda e 31 de vinho ${ }^{92}$. Embora menor que a dos gafos, ao compararmos esta ração com a dos pobres do Hospital de Santa Isabel, verificamos que os merceeiros sãos de S. Lázaro recebiam quantidades de alimentos superiores àqueles, às quais se acrescentavam algumas pitanças de carne e peixe, beneficiando, assim, de uma dieta mais rica ${ }^{93}$.

2,25 1. Cf., acima, n. 37 e Marques 1985: 70-71.

88 Cf. Olivier-Touati 1998: 463.

${ }^{89}$ AUC, IV-3.a-53-3-64 ou Rocha 2011: 232. Sobre a diminuição das quantidades a atribuir a cada leproso, veja-se Rocha 2011: 75-76 e Rocha 2016: 61-62. Maria Helena da Cruz Coelho aborda igualmente o sustento dos gafos de Coimbra, em período posterior ao Regimento de 1329, em comparação com rações atribuídas a outros indivíduos, calculando mesmo as calorias diárias de cada leproso, que rondariam as 6386. Coelho 1990: 13-14; 21, n. 43.

90 Sobre estas pitanças, veja-se Rocha 2011: 73-74 e Rocha 2016: 62-69. Para uma comparação da dieta dos leprosos de Coimbra com a que era oferecida nas gafarias da província eclesiástica de Sens, consultar Olivier-Touati 1998: 461-470.

${ }^{91}$ AUC, Cofre 34: 2v ou Rocha 2011: 161. Cf. Tabela 2.

${ }_{92}$ Aqui utilizámos o mesmo método de divisão que para a ração dos leprosos. Cf., acima, n. 88.

93 Os merceeiros sãos passaram a ter direito a algumas pitanças apenas a partir do aditamento de 1346 ao regimento. Cf. Rocha 2011: 74. 
Mesmo sem referirmos as pitanças a que tinham direito, verificamos que, no conjunto de pobres e enfermos institucionalizados da cidade de Coimbra, os leprosos e pobres envergonhados que recebiam um provento na gafaria formavam um grupo de verdadeiros privilegiados, aos quais eram dados alimentos diversificados e de grande riqueza nutricional, que os ajudavam a enfrentar, no dia a dia, a sua debilitante doença.

\section{Considerações finais}

A fome marcou indelevelmente a sociedade medieval, afetando, em particular, os pobres e doentes, cuja resistência física ficava assim comprometida. Incapazes de proverem o seu próprio sustento, estes indivíduos estavam dependentes da restante sociedade e das instituições que os acolhiam para terem acesso a uma dieta que minimizasse a fraqueza dos seus corpos. Através de esmolas e da ação de confrarias e hospitais, os indigentes e enfermos acediam a um regime alimentar mais completo e rico em nutrientes como hidratos de carbono e proteínas, apesar de pobre em vitaminas e fibras. Mesmo que não muito variada, a dieta alimentar dos pobres e doentes institucionalizados de Coimbra era um privilégio, pois tinham oportunidade de consumir géneros que não estavam acessíveis a todos. Com as devidas reservas, poderemos quase afirmar que este grupo beneficiou dos "prazeres da mesa" para cuidar do corpo. 
Ana Rita Rocha

\section{ANEXO 1}

Legados pios de produtos alimentares a pobres e doentes da cidade de Coimbra (séculos XII-XIV)

\begin{tabular}{|c|c|c|c|c|c|c|c|c|}
\hline \multirow[b]{2}{*}{ Data } & \multirow[b]{2}{*}{ Beneficiários } & \multirow[b]{2}{*}{ Distribuição } & \multicolumn{5}{|c|}{ Composição do legado } & \multirow[b]{2}{*}{ Fonte } \\
\hline & & & $\begin{array}{c}\text { Pão/ } \\
\text { Cereais }\end{array}$ & Vinho & Carne & Peixe & $\begin{array}{c}\text { Não } \\
\text { especificado }\end{array}$ & \\
\hline $\mathrm{s} / \mathrm{d}$ & Pobres & Missas & $\mathrm{X}$ & $\mathrm{X}$ & $\mathrm{X}$ & & & $\begin{array}{l}\text { ANTT, Mosteiro } \\
\text { de Santa Cruz de } \\
\text { Coimbra, } 1 .^{\mathrm{a}} \text { inc., } \\
\text { DP, mç. } 14, \text { n. }^{\circ} 36 .\end{array}$ \\
\hline $\mathrm{s} / \mathrm{d}$ & Cativos & - & $\mathrm{X}$ & $\mathrm{X}$ & & & & $L P: 727$. \\
\hline 1110 NOV 9 & Pobres & Aniversário & $\mathrm{X}$ & $\mathrm{X}$ & & & & $L P: 67-69$ \\
\hline $\begin{array}{c}1110 \text { DEZ } \\
25\end{array}$ & Pobres & Aniversário & $\mathrm{X}$ & $\mathrm{X}$ & & & & $L P: 363-364$. \\
\hline $1130 \mathrm{JUL}$ & Pobres & Missas & $\mathrm{X}$ & $\mathrm{X}$ & & & & $\begin{array}{l}\text { ANTT, Mosteiro } \\
\text { de Santa Cruz de } \\
\text { Coimbra, } 1 .^{\mathrm{a}} \text { inc., } \\
\text { DP, mç. } 5, \text { n. }^{\circ} 2 .\end{array}$ \\
\hline 1135 & Pobres & - & $\mathrm{X}$ & & & & & $L P: 612-613$. \\
\hline \multirow[b]{2}{*}{1149 MAIO } & Pobres & $3 \mathrm{x} / \mathrm{ano}$ & $\mathrm{X}$ & $\mathrm{X}$ & $\mathrm{X}$ & & & \multirow{2}{*}{$\begin{array}{l}\text { ANTT, Mosteiro } \\
\text { de Santa Cruz de } \\
\text { Coimbra, } 1 .^{\mathrm{a}} \text { inc., } \\
\text { DP, mç. } 3 \text {, n. } 20 \text {. }\end{array}$} \\
\hline & Pobres & $3 x /$ ano & $\mathrm{X}$ & $\mathrm{X}$ & $\mathrm{X}$ & & & \\
\hline $1160 \mathrm{ABR}$ & Pobres & Missas & $\mathrm{X}$ & $\mathrm{X}$ & & & & $\begin{array}{l}\text { ANTT, Mosteiro } \\
\text { de Santa Cruz de } \\
\text { Coimbra, } 11^{\mathrm{a}} \text { inc., } \\
\text { DP, mç. } 14, \text { n. } 29 .\end{array}$ \\
\hline $1177-1180$ & Pobres & - & $\mathrm{X}$ & & & & & $L P: 367-368$. \\
\hline $1220 \mathrm{MAR}$ & Leprosos & - & & & & $\mathrm{X}$ & & TEP: 248. \\
\hline $1222 \mathrm{JUL}$ & Leprosos & - & & & & & $\mathrm{X}$ & TEP: 250. \\
\hline 1240 & Pobres & Missas & $\mathrm{X}$ & $\mathrm{X}$ & $\mathrm{X}$ & & & $\begin{array}{l}\text { ANTT, Mosteiro de } \\
\text { S. Jorge de Coimbra, } \\
\text { 1. }{ }^{a} \text { inc., mç. } 6, \text { n. }^{\circ} 5 .\end{array}$ \\
\hline $\begin{array}{c}1236 \text { AGO } \\
27\end{array}$ & Pobres & - & $\mathrm{X}$ & & & & & TEP: 260. \\
\hline $\begin{array}{c}1268 \text { MAR } \\
08\end{array}$ & Leprosos & - & & & & & $\mathrm{X}$ & TEP: 303. \\
\hline 1280 JAN 29 & Leprosos & - & & & & & $\mathrm{X}$ & TEP: 319. \\
\hline \multirow{4}{*}{$\begin{array}{c}1285 \text { MAR } \\
16\end{array}$} & $\begin{array}{c}\text { Donas doen- } \\
\text { tes (mosteiro } \\
\text { de Celas da } \\
\text { Ponte) }\end{array}$ & - & & & & & $\mathrm{X}$ & \multirow{4}{*}{ TEP: 337-338. } \\
\hline & $\begin{array}{l}\text { Donas doen- } \\
\text { tes (mosteiro } \\
\text { de Celas da } \\
\text { Ponte) }\end{array}$ & - & & & & & $\mathrm{X}$ & \\
\hline & $\begin{array}{l}\text { Donas doen- } \\
\text { tes (mosteiro } \\
\text { de Celas da } \\
\text { Ponte) }\end{array}$ & - & & & & & $\mathrm{X}$ & \\
\hline & Leprosos & - & & & & & $\mathrm{X}$ & \\
\hline
\end{tabular}


"Dar de comer a quem tem fome": a dieta alimentar dos pobres e doentes de Coimbra na Idade Média

\begin{tabular}{|c|c|c|c|c|c|c|c|c|}
\hline 1286 JAN 03 & Leprosos & - & & & & & $\mathrm{X}$ & $\begin{array}{c}\text { ANTT, Colegiada de } \\
\text { S. Joẫo de Almedina } \\
\text { de Coimbra, mç. } 1 \text {, } \\
\text { n. }{ }^{\circ} \text {. }\end{array}$ \\
\hline 1292 FEV 16 & Leprosos & - & & & & $\mathrm{X}$ & & $\begin{array}{l}\text { ANTT, Mosteiro } \\
\text { de Santa Cruz de } \\
\text { Coimbra, 2. inc., } \\
\text { mç. } 4 \text {, n. "Alm. } 11 \text {, } \\
\text { n. }{ }^{\circ} 27, \text { mç. } 6 \text { ". }\end{array}$ \\
\hline $\begin{array}{c}1292 \mathrm{DEZ} \\
14\end{array}$ & Pobres & Fim do ano & $\mathrm{X}$ & & $\mathrm{X}$ & $\mathrm{X}$ & & $T E P: 341$. \\
\hline 1293 FEV 15 & Pobres & $\begin{array}{l}\text { Sábado, } \\
\text { trigésimo, } \\
\text { ano }\end{array}$ & & & & & $\mathrm{X}$ & TEP: 342. \\
\hline \multirow[t]{2}{*}{1294 JUN 09} & $\begin{array}{c}\text { Pobres } \\
\text { envergonha- } \\
\text { dos e outros } \\
\text { pobres } \\
\end{array}$ & Sábado & $\mathrm{X}$ & & & $\mathrm{X}$ & & \multirow{2}{*}{$\begin{array}{l}\text { ANTT, Cabido da Sé } \\
\text { de Coimbra, 2. a inc., } \\
\text { mç. } 79, \text { n. }^{\circ} 3399 .\end{array}$} \\
\hline & $\begin{array}{c}\text { Pobres en- } \\
\text { vergonhados }\end{array}$ & Trinta dias & $\mathrm{X}$ & & $\mathrm{X}$ & & & \\
\hline \multirow{2}{*}{$\begin{array}{c}1296 \text { MAR } \\
19\end{array}$} & Pobres & Sábado & $\mathrm{X}$ & $\mathrm{X}$ & & & & \multirow{2}{*}{$T E P: 359}$. \\
\hline & Pobres & Trinta dias & $\mathrm{X}$ & $\mathrm{X}$ & $\mathrm{X}$ & & & \\
\hline \multirow{2}{*}{$\begin{array}{c}1297 \text { MAR } \\
23\end{array}$} & $\begin{array}{c}\text { Pobres en- } \\
\text { vergonhados }\end{array}$ & Sábado & & & & & $\mathrm{X}$ & \multirow{2}{*}{$\begin{array}{l}\text { ANTT, Cabido da Se } \\
\text { de Coimbra, 2. }{ }^{\text {a inc., }} \\
\text { mç. } 58, \text { n. }^{\circ} 2153 \text {. }\end{array}$} \\
\hline & $\begin{array}{c}\text { Pobres en- } \\
\text { vergonhados }\end{array}$ & Trinta dias & $\mathrm{X}$ & $\mathrm{X}$ & $\mathrm{X}$ & & & \\
\hline 1303 JAN 27 & Leprosos & - & & & & & $\mathrm{X}$ & $\begin{array}{l}\text { ANTT, Cabido da Sé } \\
\text { de Coimbra, 2.a inc., } \\
\text { mç. } 93, \text { n. }{ }^{\circ} 4457 .\end{array}$ \\
\hline \multirow{4}{*}{$\begin{array}{c}1310 \mathrm{AGO} \\
23\end{array}$} & Leprosos & - & & & & & $\mathrm{X}$ & \multirow{4}{*}{$\begin{array}{c}\text { Campos 2012: vol. } \\
\text { 2, 120-121. }\end{array}$} \\
\hline & Pobres & Sábado & $\mathrm{X}$ & & & $\mathrm{X}$ & & \\
\hline & Pobres & $\begin{array}{c}\text { Missas do } \\
\text { mês }\end{array}$ & $\mathrm{X}$ & & $\mathrm{X}$ & & & \\
\hline & Pobres & $\begin{array}{c}\text { Missas do } \\
\text { ano }\end{array}$ & $\mathrm{X}$ & & $\mathrm{X}$ & & & \\
\hline 1318 JUN 17 & Leprosos & - & & & & & $\mathrm{X}$ & TEP: 405. \\
\hline \multirow{2}{*}{$\begin{array}{c}\text { a. } 1318 \mathrm{JUL} \\
06\end{array}$} & Pobres & Sábado & $\mathrm{X}$ & & & $\mathrm{X}$ & & \multirow{2}{*}{ TEP: 645.} \\
\hline & Pobres & Trinta dias & $\mathrm{X}$ & $\mathrm{X}$ & $\mathrm{X}$ & & & \\
\hline 1322 JUL 18 & Doentes & Matinas & $\mathrm{X}$ & & & & & TEP: 428. \\
\hline $\begin{array}{c}1322 \text { OUT } \\
27 \\
\end{array}$ & $\begin{array}{c}\text { Pobres en- } \\
\text { vergonhados }\end{array}$ & - & $\mathrm{X}$ & & $\mathrm{X}$ & & & TEP: 444 \\
\hline 1324 JUL 13 & Pobres & $\begin{array}{l}\text { Missas } \\
\text { anuais }\end{array}$ & $\mathrm{X}$ & & $\mathrm{X}$ & & & TEP: 467. \\
\hline $\begin{array}{c}1331 \text { MAR } \\
15\end{array}$ & $\begin{array}{l}\text { Donas doen- } \\
\text { tes (mosteiro } \\
\text { de Santa } \\
\text { Clara) } \\
\end{array}$ & - & & & $\mathrm{X}$ & & & $\begin{array}{c}\text { ANTT, Convento } \\
\text { de Santa Clara de } \\
\text { Coimbra, DP, mç. } 19 \text {, } \\
\text { n. }{ }^{\circ} 30 . \\
\end{array}$ \\
\hline 1132 FEV 19 & Leprosos & - & & & & & $\mathrm{X}$ & PMM: 389-392. \\
\hline
\end{tabular}




\begin{tabular}{|c|c|c|c|c|c|c|c|}
\hline $\begin{array}{c}\text { a. } 1332 \mathrm{ABR} \\
24\end{array}$ & Pobres & $\begin{array}{c}\text { Aniversário } \\
\text { (17 de } \\
\text { agosto) }\end{array}$ & & & & $\mathrm{X}$ & $\begin{array}{l}\text { ANTT, Colegiada de } \\
\text { S. Pedro de Coimbra, } \\
\text { liv. } 1 \text {, fl. 4v. }\end{array}$ \\
\hline 1356 ABR 08 & Pobres & - & $\mathrm{X}$ & $\mathrm{X}$ & & & $\begin{array}{l}\text { ANTT, Convento } \\
\text { de Santa Ana de } \\
\text { Coimbra, mç. 4, s/n. }\end{array}$ \\
\hline \multirow{2}{*}{$\begin{array}{c}1364 \mathrm{AGO} \\
23\end{array}$} & Pobres & $\begin{array}{l}8 .^{\circ} \text { dia da } \\
\text { soterração }\end{array}$ & $\mathrm{X}$ & & $\mathrm{X}$ & & \multirow{2}{*}{$\begin{array}{l}\text { ANTT, Cabido da Sé } \\
\text { de Coimbra, } 2 .^{\mathrm{a}} \text { inc., } \\
\text { mç. } 10, \text { n. }^{\circ} 454 .\end{array}$} \\
\hline & Pobres & Ano & $\mathrm{X}$ & $\mathrm{X}$ & & & \\
\hline
\end{tabular}

\section{REFERENCIAS}

\section{Fontes Inéditas}

Coimbra, AUC, Cofre, n. ${ }^{\circ} 34$.

Coimbra, AUC, Hospital Real de Coimbra, IV-2. a E-7-5-1.

Coimbra, AUC, Hospital de S. Lázaro, IV-3a a-53-3-64.

Lisboa, ANTT, Cabido da Sé de Coimbra, 2. a inc., mç. 10, n.o 454.

Lisboa, ANTT, Cabido da Sé de Coimbra, 2. a inc., mç. 58, n. 2153.

Lisboa, ANTT, Cabido da Sé de Coimbra, 2. a inc., mç. 74, n. 2966.

Lisboa, ANTT, Cabido da Sé de Coimbra, 2. a inc., mç. 79, n.o 3399.

Lisboa, ANTT, Cabido da Sé de Coimbra, 2. a inc., mç. 93, n. 4457.

Lisboa, ANTT, Mosteiro de Santa Cruz de Coimbra, 1. ${ }^{\mathrm{a}}$ inc., DP, mç. 3, n. ${ }^{\circ} 20$.

Lisboa, ANTT, Mosteiro de Santa Cruz de Coimbra, 1. a inc., DP, mç. 5, n. ${ }^{\circ} 2$.

Lisboa, ANTT, Mosteiro de Santa Cruz de Coimbra, 1. a inc., DP, mç. 14, n. 29.

Lisboa, ANTT, Mosteiro de Santa Cruz de Coimbra, 1. a inc., DP, mç. 14, n. 36.

Lisboa, ANTT, Mosteiro de Santa Cruz de Coimbra, 2. ${ }^{a}$ inc., mç. 4, n. "Alm. 11, n. ${ }^{\circ} 27$, mç. 6".

Lisboa, ANTT, Convento de Santana de Coimbra, mç. 4, s/n (1356 ABRIL 8).

Lisboa, ANTT, Convento de Santana de Coimbra, mç. 4, s/n (1367 OUTUBRO 18).

Lisboa, ANTT, Convento de Santa Clara de Coimbra, DP, mç. 19, n. 30.

Lisboa, ANTT, Mosteiro de S. Jorge de Coimbra, 1. a inc., mç. 6, n. 5.

Lisboa, ANTT, Colegiada de S. Pedro de Coimbra, liv. 1.

Lisboa, ANTT, Colegiada de S. Pedro de Coimbra, liv. 4.

Lisboa, ANTT, Colegiada de S. João de Almedina de Coimbra, mç. 1, n. ${ }^{\circ} 4$.

Lisboa, ANTT, Colegiada de Santa Justa de Coimbra, mç. 1, n. 7.

\section{Fontes Impressas}

Garcia y Garcia, A. (ed.) (1982), Synodicon Hispanum. II. Portugal, Biblioteca de Autores Cristianos, Madrid.

[TEP] Morujão, M. do R. B. (coord.) (2010), Testamenta Ecclesiae Portugaliae 
"Dar de comer a quem tem fome": a dieta alimentar dos pobres e doentes de Coimbra na Idade Média

(1071-1325), Centro de Estudos de História Religiosa/Universidade Católica Portuguesa, Lisboa.

[PMM] Paiva, J. P. (coord.) (2003), Portugaliae Monumenta Misericordiarum, vol. 2, Antes da Fundação das Misericórdias, União das Misericórdias Portuguesas, Lisboa.

Reuter, A. E. (1938), Chancelarias Medievais Portuguesas, vol. 1, Documentos de D. Afonso Henriques, Instituto Alemão da Universidade de Coimbra, Coimbra.

[LP] Rodrigues, M. A. (coord.) (1999), Livro Preto. Cartulário da Sé de Coimbra. Edição Critica. Texto Integral, Arquivo da Universidade, Coimbra.

\section{Estudos}

Adamson, M. W. (2004), Food in Medieval Times, Greenword Press, Westport, Connecticut, London.

Beirante, M. A. (1990), Confrarias medievais portuguesas, M. A. Beirante, Lisboa.

Beirante, M. A. (2011a), "Para a história da morte em Portugal (sécs. XII-XIV)", in Territórios do sagrado: crenças e comportamentos na Idade Média em Portugal, Edições Colibri, Lisboa, 9-33.

Beirante, M. A. (2011b), "Ritos alimentares em algumas confrarias portuguesas medievais", in Territórios do sagrado: crenças e comportamentos na Idade Média em Portugal, Edições Colibri, Lisboa, 185-197.

Bertran i Roigé, P. (1979), “El menjador de l'Almoina de la Catedral de Lleida. Notes sobre l'alimentació dels pobres lleidatans al 1338”, Ilerda 40: 89-124.

Braga, I. D. (2015), Sabores e Segredos. Receituários conventuais portugueses da Época Moderna, Imprensa da Universidade de Coimbra e Annablume Editora, Coimbra.

Brodman, J. W. (1998), Charity and Welfare: Hospitals and the Poor in Medieval Catalonia, University of Philadelphia Press, Philadelphia.

Campos, M. A. A. (2012), Santa Justa de Coimbra na Idade Média: o espaço urbano, religioso e socio-económico, 2 vols., Dissertação de doutoramento em História da Idade Média apresentada à Faculdade de Letras da Universidade de Coimbra.

Cândido, G. da S. (2014), “"Não destruas por causa da comida a obra de Deus». Restrições e recomendações alimentares na legislação sinodal portuguesa (séculos XIV a XVI)”, Revista de História da Sociedade e da Cultura 14: 133-159.

Cappelli, A. (1988, 6. ${ }^{a}$ ed.), Cronologia, cronografia e calendario perpetuo dal principio dell'èra cristiana ai nostri giorni: tavole cronologico-sincrone e quadri sinottici per verificare le date storiche, Ulrico Hoepli, Milão.

Chiffoleau, J. (2011), La comptabilité de l'au-delà: Les hommes, la mort et la religion dans la region d'Avignon à la fin du Moyen Âge (vers 1320 - vers 1480), Éditions Albin Michel, Paris.

Coelho, M.H. da C. (1990), "Apontamentos sobre a Comida e a Bebida do Campesinato Coimbrão em Tempos Medievos”, Homens, Espaços e Poderes (séculos XI a XVI). I-Notas do Viver Social, Livros Horizonte, Lisboa, 9-22.

Coelho, M. H. da C. (1992), "As Confrarias medievais portuguesas: espaços de solidariedades na vida e na morte", in Actas da XIX Semana de Estudios Medievales. 
Estella'92, Gobierno de Navarra - Departamento de Educación y Cultura, Pamplona, 149-183.

Coelho, M.H.da C. (2013), O Município de Coimbra-Monumentos Fundacionais, Câmara Municipal de Coimbra e Imprensa da Universidade de Coimbra, Coimbra.

Cortonesi, A. (2001), "Autoconsumo e mercado: a alimentação rural e urbana na Baixa Idade Média”, in J.-L. Flandrin e M. Montanari (eds.), História da Alimentação, vol. 2, Da Idade Média aos tempos actuais, Terramar, Lisboa, 31-41.

Geremek, B. (1995), A Piedade e a Forca - História da Miséria e da Caridade na Europa, Terramar, Lisboa.

Gomes, S. A. (2007), In Limine Conscriptionis. Documentos, Chancelaria e Cultura no Mosteiro de Santa Cruz de Coimbra (Séculos XII a XIV), Palimage Editores e CHSC, Viseu.

Gomes, S. R. F. (2011), Territórios medievais do pescado do reino de Portugal, tese de Mestrado em Alimentação - Fontes, Cultura e Sociedade apresentada à Faculdade de Letras da Universidade de Coimbra.

Gonçalves, I. (2007), “A propósito do pão da cidade na Baixa Idade Média”, in C. G. da Silva (coord.), História da Alimentação, Turres Veteras, IX, Edições Colibri/Câmara Municipal de Torres Vedras/Instituto Alexandre Herculano, Lisboa, 49-72.

Gonçalves, I. (2010), “A Alimentação”, in J. Mattoso (dir.) História da Vida Privada, B. V. e Sousa (coord.), A Idade Média, Círculo de Leitores e Temas e Debates, Lisboa, 226-259.

Grieco, A. J. (2001), "Alimentação e classes sociais no fim da Idade Média e no Renascimento", in J.-L. Flandrin e M. Montanari (eds.), História da Alimentação, vol. 2, Da Idade Média aos tempos actuais, Terramar, Lisboa, 83-93.

Horden, P. (1988), "A Discipline of Relevance: The Historiography of the Later Medieval Hospital”, Social History of Medicine 1(3): 359-374.

Le Blévec, D. (2000), La part du pauvre: L'assistance dans les pays du Bas-Rhône du XIIe siècle au milieu du XVe siècle, 2 vols, École Française de Rome, Roma.

Le Goff, J. (2008), La Civilisation de l'Occident Médieval, Éditions Flammarion, Paris.

López Alonso, C. (1986), La pobreza en la España medieval, Ministerio de Trabajo y Seguridad, Madrid.

Macedo, F. P. de (2000), “O Hospital de Santa Isabel junto ao Mosteiro de Santa Claraa-Velha de Coimbra”, in C. Amado e L. Mata (coords.), João Afonso de Santarém $e$ a assistência hospitalar escalabitana durante o Antigo Regime, Câmara Municipal de Santarém, Santarém, 144-159.

Marques, A. H. de O. (1978, 3. ${ }^{\mathrm{a}}$ ed.), Introdução à história da agricultura em Portugal: a questão cerealífera durante a Idade Média, Cosmos, Lisboa.

Marques, A. H. de O. (1985), "Pesos e Medidas”, in J. Serrão (dir.), Dicionário de História de Portugal, vol. V, Paróquia-Sintra, Livraria Figueirinhas, Porto, 67-72.

Marques, A. H. de O. (2010, 6. ${ }^{\mathrm{a}}$ ed.), A Sociedade Medieval Portuguesa. Aspectos de Vida Quotidiana, A Esfera dos Livros, Lisboa.

Mollat, M. (2006, 3. ${ }^{\mathrm{a}}$ ed.), Les Pauvres au Moyen Âge, Éditions Complexe, Bruxelas. 
"Dar de comer a quem tem fome": a dieta alimentar dos pobres e doentes de Coimbra na Idade Média

Montanari, M. (1993), El hambre y la abundancia. Historia e cultura de la alimentación en Europa, Crítica, Barcelona.

Olivier-Touati, F. (1998), Maladie et société au Moyen Âge. La lèpre, les lépreux et les léproseries dans la province ecclésiastique de Sens jusqu'au milieu du XIVe siècle, De Boeck Université, Bruxelas.

Rawcliffe, C. (1999), Medicine for the soul: the life, death, and resurrection of an English medieval hospital, St Giles's, Norwich, c. 1249-1550, Sutton Publishing, Stroud.

Rocha, A. R. S. da (2011), A Institucionalização dos Leprosos. O Hospital de S. Lázaro de Coimbra nos séculos XIII a XV, Dissertação de mestrado em História da Idade Média apresentada à Faculdade de Letras da Universidade de Coimbra.

Rocha, A. R. (2016), “A dieta dos leprosos numa gafaria medieval: o caso de Coimbra”, Revista de História da Sociedade e da Cultura 16: 55-73.

Rubin, M. (1991), "Imagining Medieval Hospitals: Considerations on the cultural meaning of institutional change", in J. Barry, C. Jones (eds.), Medicine and Charity Before the Welfare State, Routledge, Londres.

Rucquoi, A. (1984), "Alimentation des riches, alimentation des pauvres dans une ville castillane au XVe siècle", in Manger et Boire au Moyen Âge, Actes du Colloque de Nice (15-17 octobre 1982), t. I, Aliments et Société, Les Belles Lettres, Paris, 297312.

Saunier, A. (1993), "Le pauvre malade" dans le cadre hospitalier medieval (France du Nord, vers 1300-1500), Éditions Arguments, Paris.

Tavares, M.J.P. F. (1989), Pobreza e Morte em Portugal na Idade Média, Editorial Presença, Lisboa.

Varandas, C. P. R. (1999), A Colegiada de S. Pedro de Coimbra das origens ao final do século XIV: estudo económico e social, 2 vols., Dissertação de mestrado em História Medieval apresentada à Faculdade de Letras da Universidade de Coimbra. 